Full-text Available Online at www.ajol.info and www.bioline.org.br/ja
J. Appl. Sci. Environ. Manage. Dec. 2016

Vol. 20 (4) 919-924

\title{
The Abundance and Composition of Crabs (Decapoda) in Uta Ewa Brackish Water, Akwa Ibom State, South-South, Nigeria
}

*11ESENOWO, IK; AKPAN, AU; EGWALI, EC; AKPABIO, EE

Department of Zoology, University of Uyo, Uyo, Akwa Ibom State

E-mail: imehesenowo@yahoo.com

\begin{abstract}
Study on the abundance and composition of crabs in Uta Ewa brackish water was carried out between January and May 2012 at two sampling stations. The physicochemical parameters of the water were measured in situ using standard methods according to APHA (1998). Crabs species were collected at two sampling stations using square lift net trap, while at low tide, crab species were collected by hand-picking at random and preserved in a chest box for identification. Air and Water temperature ranges from $27.9-31.6{ }^{\circ} \mathrm{C}$ and $28.2-28.9{ }^{\circ} \mathrm{C}$ respectively, while Dissolved Oxygen and Salinity were between 3.28-4.09 $\mathrm{mg} / \mathrm{L}$ and 7.5-12.9 ppt respectively. The results of the physicochemical parameters were within limits of the National Environmental Standards and Regulations Enforcement Agencies for aquatic life. A total of 107 crabs were collected from the two sampling stations. Goniopsis pelii was the most abundant in Station 1 accounting for $57.9 \%$, followed by Callinectes amnicola 26.3\%, while in Station 2, Callinectes amnicola was the most abundant accounting for $46.6 \%$ of the percentage abundance. Station 2 had the highest Shannon diversity index of 1.22, while Station 1 had 1.15. The abundance and composition of crab species in the study areas is an indication that the area is an important ecological zone for benthos macroinvertebrates conservation. (C) JASEM
\end{abstract}

http://dx.doi.org/10.4314/jasem.v20i4.3

Keywords: Uta Ewa, Brackish Water, Physicochemical Parameters, Abundance, Composition, Crab species,

Crabs are highly important group and are one of the most common marine decapods, with approximately 5000 species described worldwide (Braga et al., 2005).

Although there are some freshwater and brackish water forms occupying the littoral, supra littoral and even up shore zones, they are also dominant in many estuarine habitats where salinity and temperatures can fluctuate dramatically daily ( $\mathrm{Ng}$ et al., 2008). The majority of crab species occur in tropical and subtropical regions as compared to temperate and cold regions (Fransozo and Negreiros-Fransozo, 1996; Boschi, 2000).

In the benthic communities, the crabs contribute immensely to the biodiversity and ecosystem function, while they are also source of human food (Hendrickx, 1995). Crabs are important within estuarine food webs, providing food for fish (Thomas et al., 1990; Heck and Coen, 1995). According to Heck and Coen, (1995), the estuarine and mangroves are major nursery grounds for a variety of juvenile fish and many of these fish are dependent on crab larvae for food. Also, it is reported that crabs together with other macro-benthic invertebrates, constitute the link between the unavailable nutrients in detritus and useful protein materials in fish and shellfish (Adebisi, 1989; Ajao and Fagade, 1990; Idowu and Ugwumba, 2005). The abundance and composition of living organism in any aquatic habitat is very important in the measure of the productivity and quality of the aquatic environment. In brackish and mangrove environment in tropics and sub-tropics; Geryonmaritae, Ocypode africana, Goniopsis pelii, Sesarma reticulatum, Uca tangerii, Callinectes amnicola, C. pallidus, C. marginatus, Cardiosoma armatum and Gecarcinus weileri are the common crab species that are found (Fransozo and NegreirosFransozo, 1996).

The crab species, Callinectes amnicola, Ocypode africana, Sesarma reticulatum along with Goniopsis pelii and Uca tangerii are reported to be the most abundant crab species in the water bodies of the brackish and mangrove environment in Nigeria as reported by Chindah et al., (2000) in New Calabar River, Cross River State; Lawal-Are and Kusemiju, (2000) in Badagry Lagoon, Lagos State, and Onadeko et al., (2015) in Lagos Lagoon, Lagos State. The dearth of baseline information on the abundance and composition of crabs species in Uta Ewa brackish water, Akwa Ibom State, Nigeria, form the objective for this study.

\section{MATERIALS AND METHODS}

Study Area: Uta Ewa estuary is located at latitude $40^{\circ} 32^{\prime}$ to $40^{\circ} 52^{\prime} \mathrm{N}$ and longitude $70^{\circ} 25^{\prime}$ to $70^{\circ} 45^{\prime} \mathrm{E}$ (Fig. 1). The estuary lies on the western bank of Enong creek about $12 \mathrm{~km}$ from the mouth of Imo River, where drainage has broken the coastal area into a jigsaw of irregular shaped tidal flat. Characteristically, the area is typical of an estuarine tidal water zone with fresh water input from Imo River and with extensive mangrove swamps and intertidal mud flats. The estuary is bounded by thick mangrove dominated by Rhizophora species and interspersed by Nypa palm. The main occupation of the people occupying the areas is fishing; other activities such as trading on fish; both fresh and smoked, fire wood cutting and water transportation system are also carried out. 
Two sampling stations with unique ecologically setting and human activities were established along the length of the estuarine. The sampling stations were about two kilometres apart from each other.

Station 1is located upstream of the Uta Ewa estuary with human settlement and local market on the left flank of the shoreline. Vegetation is sparse with mainly mangrove Rhizophora sp. and Nypa palm. The station is very shallow and the bottom when expose at low tide is made of fine sand. Human activities included; logging of the mangrove, sand dredging, washing of boats, canons and fishing nets, and swimming.

Station 2is situated downstream of the estuary with no human settlement. On the shorelines are thick vegetation of mangrove Rhizophorasp. and Nypa palm. The station is slightly deep and at low tide, the greater part of the bottom mud flat is exposed. Human activities in this station are minimal, with only fishing activity

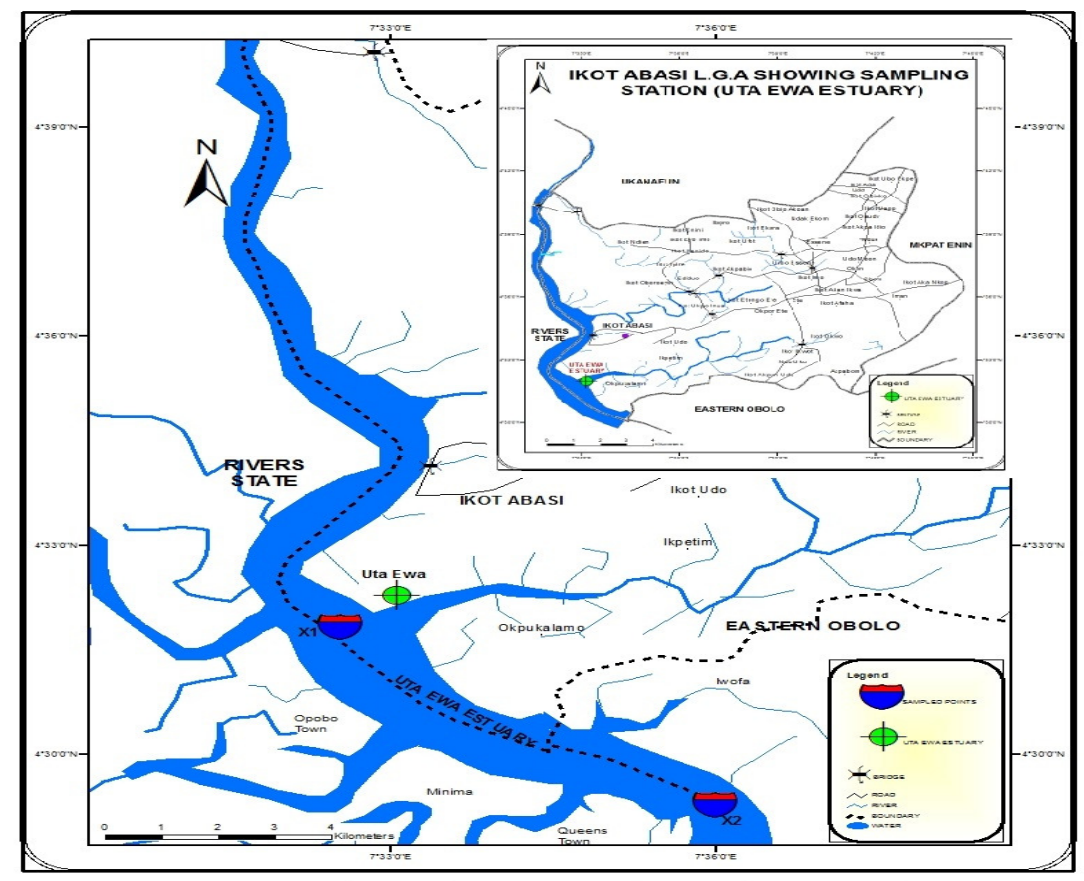

Fig 1. Map of study area showing Uta Ewa Beach and the sampling stations

Physico-chemical parameters: The following physical and chemical parameters were determined: air temperature, water temperature, $\mathrm{pH}$, Dissolved Oxygen (DO), depth, transparency, salinity. Apart from air and water temperature, transparency, salinity and depth were done in situ, Dissolved Oxygen was determined in the laboratory. Surface water samples were collected in 2L Glass bottles containers after they were rinsed with distilled water from each sampling stations.

Determination of Temperature: Temperature was taken using a centigrade mercury-in-glass thermometer. Air temperature was measured by holding the thermometer in the air for 3 minutes. Water temperature was measured by inserting the thermometer to a depth of $10 \mathrm{~cm}$ into the water for 3 minutes. Reading was taken three times and mean value recorded. The results were expressed as degree Celsius $\left({ }^{\circ} \mathrm{C}\right)$.

Determination of Dissolved Oxygen (DO): Water samples from each station was collected into $250 \mathrm{~mL}$ stoppered samplings bottles without air bubbles and fix immediately with Manganous sulphate solution and Potassium iodide, sodium hydroxide and sodium azide solution. In the laboratory, the DO concentration of the water sample was determined using the azide modification of the iodometric method as reported by (APHA, AWWA, WEF, 1998). The result was expressed as $\mathrm{mg} / \mathrm{L}$.

Determination of Salinity: An Extech meter Model ExStik EC400 was used to measure salinity. The meter was calibrated with $3.3 \mathrm{~mol}$ solution of potassium chloride. The glass electrode of the meter was inserted into the water sample after being rinsed 
with distilled water and measurement was taken after the reading had stabilized. The result for salinity was expressed as part per thousand $(\% o)$.

Determination of $\mathrm{pH}$ : The $\mathrm{pH}$ was measured using electronic $\mathrm{pH}$ meter (Oakton waterproof Instruments pHtestr 10). The $\mathrm{pH}$ meter was standardized using prepared buffer solution according to the manufacturer's instruction. Water sample was put into a beaker after it was rinsed with distilled water. The glass electrode of the meter was inserted into the water sample and measurement was taken after the reading had stabilized.

Determination of Water Depth: An improvised long pole was dipped into the river; the pole was marked and later measured out with a measuring tape. The results was expressed as meter.

Determination of transparency: Transparency was measured using a Secchi disc measuring about $20 \mathrm{~cm}$ in diameter. The Secchi disc was lowered into the water and the suspended rope that was marked was later measured out. The result was expressed as meter.

Collection of Crab Species: Crab species were collected between January and May 2012 at two (2) sampling points. Crabs species were collected using square lift net trap, while at low tide, crab species were collected by hand-picking at random. The crabs collected were preserved in a chest box in the field and later transferred to the Department of Zoology Laboratory, University of Uyo, for sorting and identification according to Lawal-Are (2009).

Identification of Crab Species: The collected crabs were identified to species level using identification keys provided by Schneider (1990); Dahdouh-Guebas et al. (1999); Martin and Davis (2001).

Data Analysis: Microsoft Excel (2007) was used for Data analysis for the percentage composition and abundance of the crabs, mean and standard deviation of the physicochemical parameters of the study stations, while version 3 of PAST Software Design was used to determine the Shannon Diversity index of the Crabs community composition.

\section{RESULTS AND DISCUSSION}

The results of the physicochemical parameters measured in Uta Ewa brackish water is presented in Table 1

Table 1: Showing the physicochemical parameters measured in Station 1 and 2 in Uta Ewa blackish water

\begin{tabular}{lllll}
\hline Parameter & \multicolumn{2}{c}{ Station 1 } & \multicolumn{2}{c}{ Station 2 } \\
\hline & Range & Mean \pm SD & Range & Mean \pm SD \\
Air Temperature $\left({ }^{\circ} \mathrm{C}\right)$ & $27.9-31.6$ & $29.86 \pm 1.55$ & $28.6-30.3$ & $29.56 \pm 0.69$ \\
Water Temperature $\left({ }^{\circ} \mathrm{C}\right)$ & $28.2-28.9$ & $28.4 \pm 0.29$ & $28.1-28.9$ & $28.36 \pm 0.36$ \\
Dissolved Oxygen $(\mathrm{mg} / \mathrm{L})$ & $3.28-4.09$ & $3.71 \pm 0.40$ & $3.55-3.79$ & $3.68 \pm 0.10$ \\
Salinity $(\mathrm{ppt})$ & $7.5-12.9$ & $10.14 \pm 2.53$ & $0-4.3$ & $2.98 \pm 2.05$ \\
pH & $7.3-7.7$ & $7.44 \pm 0.19$ & $6.40-7.0$ & $6.74 \pm 0.24$ \\
Depth $(\mathrm{m})$ & $2.5-11$ & $5.48 \pm 3.30$ & $1.50-4.0$ & $3.24 \pm 1.12$ \\
Transparency $(\mathrm{m})$ & $0.45-0.83$ & $0.66 \pm 0.19$ & $1.10-1.65$ & $1.50 \pm 0.23$ \\
\hline
\end{tabular}

The lowest mean air temperature $(29.56 \pm 0.69)$ was reported in Station 2 while the highest mean value was reported in Station $1(29.86 \pm 1.55)$. The lowest mean water temperature; $28.36 \pm 0.36$, was reported in Station 2, while the highest mean value was reported in Station 1. The lowest mean dissolved oxygen; $3.71 \pm 0.40$, was recorded in Station 1 while the highest mean value $(3.68 \pm 0.10)$ was recorded in Station 2 . The lowest mean salinity $(2.98 \pm 2.05)$ was recorded in Station 2 while the highest mean value; $10.14 \pm 2.53$, was recorded in Station 1.Higher $\mathrm{pH}$ were recorded in Stations 1 while the lowest was in Station 2. Station 2 recorded the lowest mean water depth while the highest mean value was in Station 1. Transparency recorded the lowest mean value in Station 2 while the highest was recorded in Stations 1.

The physicochemical parameters of any water body are vital ecological factors, as it directly affects oxygen consumption, metabolism, growth, moulting, hormones and survival of crustaceans (Chen et al., 1995; Medesani et al., 2001; Onadekoet al., 2015). The results for physicochemical parameter in Uta Ewa Brackish water were within limit as recommended by National Environmental Standards and Regulations Enforcement Agencies (NESREA) for aquatic life. Although salinity was low in Station 2 , this could be attributed to the intrusion of freshwater into the brackish water during low tide. Similar results were also reported by Vanessa et al., (2014) of fluctuation in salinity during high and low tides in Wouri Estuary, Douala, Cameroon.

Crabs Composition and Abundance: The Composition of crab species encountered in Uta Ewa brackish water is showed in Table 2, while Plate 1-3 are pictures of the crabs species encountered during the study period 
Table 2: The composition of crab species encountered in Uta Ewa brackish water

\begin{tabular}{llll}
\hline S/N & Family & Crab species & Common names \\
\hline $\mathbf{1}$ & Grapsidae & Goniopsis pelii & Purple mangrove crab \\
$\mathbf{2}$ & Gecarcinidae & Cardisoma armatum & Land crab \\
$\mathbf{3}$ & Ocypodidae & Ocypode africana & Ghost crab \\
$\mathbf{4}$ & Portunidae & Callinectes amnicola & Swimming crab \\
$\mathbf{5}$ & Xanthidae & Panopeus africanus & \\
\hline
\end{tabular}

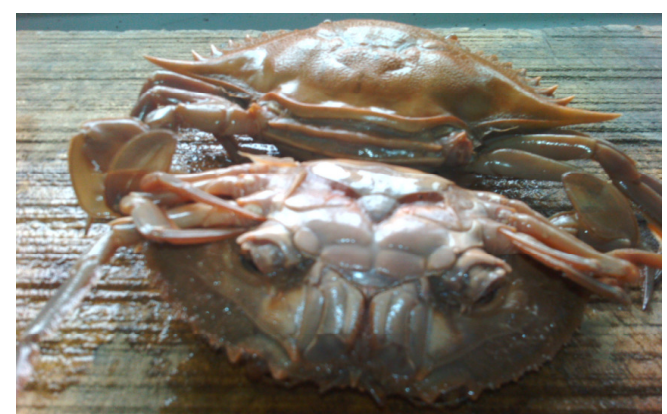

Plate 1: Callinectes amnicola (Swimming crab)

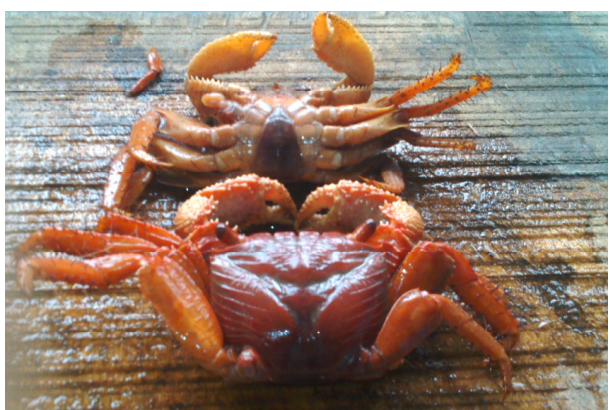

Plate 2: Panopeus africanus

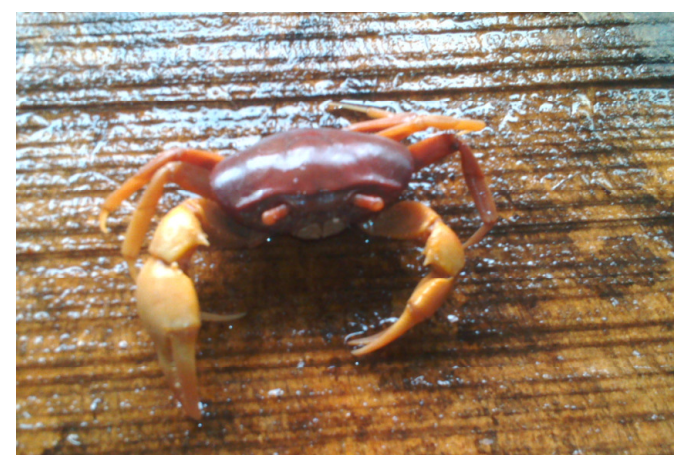

Plate 3: Cardisoma armatum (Land_crab)

A total of 107 crabs belonging to five families were recorded. Goniopsis pelii was the most abundant in Station 1 accounting for $57.9 \%$ of the percentage abundance, followed by Callinectes amnicola $26.3 \%$, while in Station 2, Callinectes amnicola was the most abundant accounting for $46.6 \%$ of the percentage abundance. Station 2 had the highest Shannon diversity index of 1.22, while Station 1 had 1.15 (Table 3).

Table 3: The Relative abundance and Shannon diversity index of the crab species in Stations 1 and 2

\begin{tabular}{|c|c|c|c|c|c|c|}
\hline $\mathbf{S} / \mathbf{N}$ & Crab species & Station 1 & $\begin{array}{l}\text { Relative } \\
\text { abundant (\%) }\end{array}$ & Station 2 & $\begin{array}{l}\text { Relative } \\
\text { abundant } \\
(\%) \\
\end{array}$ & Total \\
\hline 1 & Goniopsis pelii & 11 & 57.9 & 30 & 34.1 & 41 \\
\hline 2 & Cardisoma armatum & - & - & 3 & 3.4 & 3 \\
\hline 3 & Ocypode africana & 2 & 10.5 & 10 & 11.4 & 12 \\
\hline 4 & Callinectes amnicola & 5 & 26.3 & 41 & 46.6 & 46 \\
\hline \multirow[t]{3}{*}{5} & Panopeus africanus & 1 & 5.3 & 4 & 4.5 & 5 \\
\hline & Total & 19 & & 88 & & 107 \\
\hline & $\begin{array}{l}\text { Shannon Diversity index } \\
\left(\mathbf{H}^{\mathbf{i}}\right)\end{array}$ & 1.15 & & 1.22 & & \\
\hline
\end{tabular}

The Purple mangrove Crab; Goniopsis pelii, was the most abundant crab species encountered in Station 1, although the station is characterised with few mangrove Rhizphora species and nypa palms, the fine sandy bottom and highly perturbed activities by humans may have resulted in lower abundant and composition of crabs in the station as compared with Station 2 with muddy bottom. The Swimming crab; Callinectes amnicola, accounted for the highest abundant, while the Land crab; Cardisoma armatum 
accounted for the least abundance of the five families. This result disagreed with results of Cannicci et al. (1995) in Kenyan coast and Onadeko et al. (2015) in Lagos Lagoon coast, who reported that the Land crab was the most abundant in mangrove swampy areas. The Land crab; Cardiosoma armatum was not encountered in Station 1 and this could be explained by the fact that the species strive well in amphibious areas as also reported by Onadeko et al., (2015) a characteristic feature of Station 2 in the study area. The $C$. armatum were very sensitive to any slightest disturbance thus burrowing very fast. Callinectes amnicola is the most important and valuable edible crab at the coastal region (Chinadah et al., 2000; Lawal-Are and Kusemiju, 2000). The Mangrove crab, Goniopsis pelii was restricted to its swampy, marshy environment covered with mangrove nypha palms. Ocypode africana (Ghost crab) occurred on the sand column in the superlittoral zone nearer to the brackish water, emerging from their burrows when the tide is low and they are also noted to have affinity for foraging to survive (Strachan et al., 1999).

Conclusion: The composition and abundance of crabs species in the study areas is an indication that the area is an important ecological zone for macroinvertebrates conservation, so as to sustain its biodiversity which play a vital role in aquatic ecological services. Callinectes amnicola was the most abundant and are economically important species locally; hence the need to integrate a sustainable management practices as they are hunted on a daily basis.

\section{REFERENCES}

Adebisi, AA (1989). The physicochemical hydrology of a tropical seasonal river Upper Ogun River.Hydrologia,79: 159-165.

Ajao, EA; Fagade, SO (1990). A study of sediment communities in Lagos Lagoon, Nigeria .J. Oil Chem. Pollut, 7:085-105.

APHA, AWWA and WEF, (1998). Standard Methods for the Examination of Water and Wastewater. $20^{\text {th }}$ Edn., American Public Health Association, American Water Works Association and Water Environmental Federation, Washinton, DC, United States.

Braga, AA; Fransozo, A; Bertini, G; Fumis, PB (2005). Composition and abundance of the crabs (Decapoda, Brachyura) off Ubatuba and Caraguatatuba, Northern Coast of Sao Paulo, Brazil. Biota Neotropica 5(2): 026-34

Boschi, EE (2000). Biodiversity of marine decapod brachyurans of the Americas. Journal of Crustacean Biology, 2: 337-342
Cannicci, S; Dahdouh - Guebas, F; Anyaona, D; Vannini, M (1995). Homing in the mangrove swimming crab, Thalamita crenata (Decapoda; Portunidae), Ethnology, 100: 424-452.

Chen S; Wu J; Huner JV; Malone, RF (1995). Effects of temperature upon ablation-to-molt interval and mortality of red swamp crawfish (Procambarusclarkii) subjected to bilateral eyestalk ablation. Aquaculture 138: 191-204.

Chindah, AC; Tawari, CCB; Ifechukwude, KA (2000). The food and feeding habits of the swimming crab, Callinectes amnicola (Portunidae) of the new Calabar River, Nigeria. J. Applied Sci. Environ. Manage. 4: 051-057

Dahdouh - Guebas, F; Giuggioli, M; Oluoch, A; Vannini, M; Cannicci, S (1999). Feeding habits of nonocypodid crabs from two mangrove forests in Kenya. Bulletin Marine Science, 64(2): 291297.

Fransozo, A; Negreiros-Fransozo, ML (1996). Brazilian coastal CrustaceaDecapoda. In: Biodiversity in Brazil: 141 A First Approach (de Bicudo CE, Menezes MNA, eds). Proceedings of the Workshop Methods for the assessment of biodiversity in plants and animals, Campos do Jordão, São Paulo, Brazil, 26-30 May 1996,CNPq - ConselhoNacional de DesenvolvimentoCientíficoeTecnológico. 275287, São Paulo, Brazil.

Heck, KL Jr; Coen, LD (1995). Predation and the abundance of juvenile blue crabs: a Comparison of selected east and Gulf Coast (USA) studies. Bull. Mar. Sci., 57(3): 877 -883.

Hendrickx, ME (1995). Checklist of brachyuran crabs (Crustacea: Decapoda) from eastern tropical Pacific.Bulletin de l'Institut royal des Sciences naturelles de Belgique, Biologie 65:125-150

Idowu, EO; Ugwumba, AAA (2005). Physical, chemical and benthic faunal characteristics of a Southern Nigerian Reservoir. The Zoologist 3: 015-025.

Lawal- Are, AO; Kusemiju, K. (2000). Size composition, growth pattern and feeding habits of the blue crab Callinectes amnicola (De Rocheborne) in the Badagry Lagoon, Nigeria Journal of Science Research and Development; 4: 117-126.

Lawal-Are, AO (2009). Food and Feeding Habits of the Blue Crabs, Callinectes amnicola (de Rocheburne) from Three Different 
Interconnecting lagoons in South - West, Nigeria. European J. Sci. Res. 32 (1): 088-094.

Martin, JW; Davis, GE (2001). An update classification of the recent Crustacea. Science Series 39. Natural History Museum of Los Angeles County. 124p.

Medesani DA; López Greco, LS; Rodríguez, EM (2001). Effects of cadmium and copper on hormonal regulation of glycemia by the eyestalks in the crab Chasmagnathus granulata. Bull Environ. Contam. Toxicol. 66: 071-076.

Ng PKL; Guinot, D; Davie, PJF. (2008). Systema brachyurorum: Part I. An annotated Checklist of extant brachyuran crabs of the world. The Raffles Bulletin of Zoology, 17: 01-286.

Onadeko, AB; Lawal-Are, A O; Igborgbor, OS (2015). Habitat diversity and species richness of brachyuran crabs off University of Lagos Lagoon coast, Akoka, Nigeria. The Bioscientist 3(1): 014- 028.

Schneider, W (1990). FAO Species identification sheets for fishery purposes. Field guide to the Commercial marine resources of the Gulf of Guinea. Prepared and published with the support of the FAO Regional office for Africa Rome, FAO 1990. pp: 268.

Strachan, PH; Smith, RC; Hamilton, DAB; Taylor, AC; Atkinson, RJA (1999). Studies on the ecology and behaviour of the ghost crab, Ocypode cursor (L.) in Northern Cyprus. SCI. MAR., 63 (1): 051-060.

Thomas, JL; Zimmerman, RJ; Minello, TJ (1990). Abundance patterns of juvenile blue crabs (Callinectes sapidus) in nursery habitats of Two Texas bays. Bull. Mar. Sci., 46(1): 115-125. 